\title{
Teachers' Appraisal Methods and Job Performance: Learning from an Islamic Boarding School in Indonesia
}

\author{
Muhammad Wildan Shohib \\ Kulliyyah of Education, \\ International Islamic University Malaysia \\ Kuala Lumpur \\ wildanshohib@gmail.com
}

\author{
Azam Othman \\ Kulliyyah of Education, \\ International Islamic University Malaysia \\ Kuala Lumpur \\ azam_othman@iium.edu.my
}

\begin{abstract}
The purpose of this study was to explore the relationship between teachers' performance appraisal methods and job performance. Data were collected from 110 teachers teaching at an Islamic boarding school in Gontor, Indonesia who had two to five years of teaching experience. A 35-item Likert scale, adapted from Muwanguzi (2010), was used to collect information regarding the appraisal methods and teaching performance. The data were analyzed in a twostep approach to test the measured variables representing three latent constructs namely classroom observation, lesson planning, self-appraisal, and teachers' job performance as the criterion variable. The findings from descriptive analysis indicated that teachers perceived selfappraisal as the most preferred and effective appraisal method used by the school, while classroom observation and lesson planning were moderately used. The correlation analysis revealed positive associations between job performance and two of the TPA methods, i.e. classroom observation and self-appraisal, while lesson planning was negatively correlated with it.
\end{abstract}

Keywords: Performance appraisal, classroom observation, self-appraisal, lesson planning, job performance, instructional leadership, Islamic boarding schools

\section{INTRODUCTION}

Managing educational institutions in the $21^{\text {st }}$ century is a highly challenging task that increases in complexity as school leaders face expanded responsibilities and high expectations from education stakeholders, particularly parents and the government. Not only are school leaders required to fulfill parental and societal needs, but they are also expected to respond to the demands and pressures from politicians to improve student achievement in the pursuit of ranking and international benchmarking standards (Mulford, 2008). The race for ranking has inspired every country in the world to strive to sustain its competitive edge by reforming educational policies that can better prepare the country to cope with the complexities and challenges of globalisation. Two of the most popular educational reform initiatives are the emphasis on science and technology and the adoption of new instructional pedagogies. Having new initiatives means that policymakers must formulate effective strategies to ensure all educational institutions have the capability to provide and sustain high quality education. This capability can be enhanced through effective performance appraisal, which is the act and process of creating a work environment that enables people to perform to the best of their abilities (Blandford, 2000). 
Against this backdrop, it is imperative that educational institutions strengthen their performance management to meet the burgeoning demands of educational reforms. In this case, performance appraisal is one of the methods used to improve teachers' performance and teaching quality (Stronge, 2006) where feedback is continuously given to teachers to help them achieve school aims and objectives. Specifically, formative assessments are needed to help teachers improve their performances at the workplace. Hence, it is clear that the main objectives of performance appraisals are to evaluate and improve teachers' job performance in schools, and promote their professional growth.

Appraisal systems and practices vary from country to country. In Indonesia, teachers' performance is appraised in a system called the Teachers' Performance Appraisal (TPA) which is managed directly by school principals, school inspectors, and head teachers (Nur Lisnawati, 2003). However, the outcomes of the TPA are rarely utilized in an effective way to improve the quality of teaching and learning in Indonesian schools. This problem could be due to the absence of an effective and consistent policy and standard operating procedures in planning, implementing and monitoring the impact of the TPA on teachers' performance. Previous studies have shown that teacher factors, like the lack of accountability for results, influence teaching and learning (Verspoor, 2008), which can be addressed or overcome by having a consistent appraisal system that promotes greater teacher accountability. Having such a monitoring system in schools ensures that teachers perform their duties as expected.

In principle, teacher appraisal has the potential to improve the teaching profession and the effectiveness of teachers. When used for both accountability and instructional improvement, performance appraisal that identifies and enhances teaching quality may be considered the ideal quality assurance mechanism to assess job performance (Danielson \& McGreal, 2000). According to Armstrong (2003), TPA is useless unless it employs effective methods of appraisal with outcomes that can be seen and measured. Therefore, in order to be effective, schools must employ different TPA methods that can produce clear, beneficial and measureable outcomes. Darling-Hammond, Wise and Peace (1999) suggest three methods in carrying out TPAs in schools. They are classroom observation, self-appraisal or self-assessment, and lesson planning.

\section{Classroom Observation}

Classroom observations (CO) are carried out by the school management to observe every event that takes place in the classroom during the actual teaching and learning activities. This method is essential to assess teachers' performance in their actual teaching. Classroom observations can be held regularly, several times in a semester to meet the school's goals and objectives. This method has many benefits to teaching and learning practices. First and foremost, the school management can gather data about the school climate, quality of student-teacher interaction, classroom management, and rapport between teacher and students (Roelofs \& Sanders, 2007). This means that other relevant aspects of the teacher's performance, apart from the instructional methods used by him or her, can be captured for evaluation. However, before conducting a classroom observation, the school management should make provisions that should be applied during the observation. The provisions are included in eight major areas: lesson organization, content knowledge and relevance, presentation, instructor-student interactions, collaborative learning activities, lesson implementation, instructional materials, and student responses (Hora $\&$ Ferrare, 2013). Hence, after conducting an observation, the appraiser is required to complete a report and assessment documents for the teacher being assessed. The assessments are related to the teacher's performance in the classroom, and it is suggested that the appraiser provide solutions to solve the problems related to the teaching methods used in the instruction. 


\section{Self-Appraisal}

Self-appraisal (SA) is a teacher's evaluation of his or her own teaching performance. He or she may do so by reviewing the teaching methods used in the classroom. Self-appraisal provides information about a teacher's self-improvement, personal development and professional responsibility. Andersen et al. (2004) defined self-appraisal as not merely a method, but also, a comprehensive approach which includes philosophical attitudes and strategies for instructional improvement. Moreover, Haertel (1993) described self-appraisal as "the process of judging one's own performance for the purpose of self-improvement" (p. 131). Self-appraisal is a procedure of collecting information about a teacher's teaching performance using one or more evaluation methods and data sources. A school may assign its teachers to conduct selfappraisals either formatively or as a summative exercise. Whatever the purpose, self-appraisal is used to verify that a teacher is making progress toward a certain set of predefined goals.

\section{Lesson Planning}

Another method to evaluate teachers' performance is lesson planning (LP). A lesson plan generally consists of several stages which all teachers are required to carefully deliberate upon. It normally begins with a revision of the content taught in the previous class. The teacher may start by asking questions to recall prior learning, and then makes connections with previous content. This is done to help the students to remember the connection between the previous lesson and the present one. The second part is presenting new content where the teacher focuses on the lesson goals and objectives. In imparting the new content, the teacher might relate what students are presently learning in class with their daily lives, and further extend their understanding by applying what they know in real world contexts. The third stage is evaluation-this is where the teacher tests students' understanding by asking them comprehension or application questions.

Denner et al. (2001) looked at lesson planning as an evaluation method for instructional aspects like teaching preparation, content arrangement, teaching methods, and learning targets. According to Matters et al. (2008), most educational institutions in developed countries reported using lesson plans as a method to evaluate their teachers' performance in schools. From the 140 school districts surveyed in the study, only 4 percent did not use lesson plans for teacher appraisal.

\section{Context of the Study and Problem Statement}

Darussalam Modern Islamic Boarding School or KMI (Kulliyyatul Mu'allimin Al Islamiyyah) Gontor is one of the Islamic educational institutions located in Gontor Ponorogo East Java, Indonesia that engages in teaching Islamic subjects in order to produce the Islamic Education teachers. Judging from its name, KMI is a high school for prospective teachers. At this school, teachers do not seem to benefit from the TPA feedback although the system is in place. Even after years of implementation, the system has not succeeded in equipping teachers with the knowledge, skills and attitudes necessary to perform their duties effectively. An effective appraisal system can play a crucial role by changing and aligning the attitudes of newly recruited teachers with the norms and requirements of the teaching profession. It can also equip teachers with the practical knowledge and skills for effective teaching.

Moreover, effective appraisal in professional learning has taken a prominent position as a tool that invests in building teacher knowledge and skills (Ingvarson, 2003), and has been 
regarded as a key lever to improve teaching. A synergistic relationship must exist between teacher appraisal and professional learning if instructional practices are to be improved, as "without a clear link to professional development opportunities, the impact of teacher appraisal and performance review will be relatively limited" (Elliott, K. (2015). Although many studies have examined the relationship between performance appraisals and different independent variables in various learning institutions, few have actually investigated the specific links between the three appraisal methods and teachers' job performance, specifically in terms of how these methods would benefit an Islamic boarding school. Thus, there is a need to look at how an Islamic school, such as the one existing in Gontor, Indonesia, conducts the assessment of its teachers, and to examine the impact such assessment might have on the teachers' job performance.

\section{Research Objectives and Questions}

The present study, conducted at an Islamic boarding school in Gontor, profiled teachers' perceptions of the TPA methods (i.e., classroom observation, self-appraisal and lesson planning) used by the school, and the relationship between the perceived uses of these methods and their job performance. The research questions were:

1. What are KMI teachers' perceptions of the TPA methods used in appraising their job performance?

2. Is there a significant relationship between the perceived use of these three TPA methods and KMI teachers' job performance?

\section{Conceptual Model}

The research objectives and questions may be summarized and visualized in the following conceptual model (Figure 1). Each of the TPA methods was hypothesized to correlate positively with job performance.

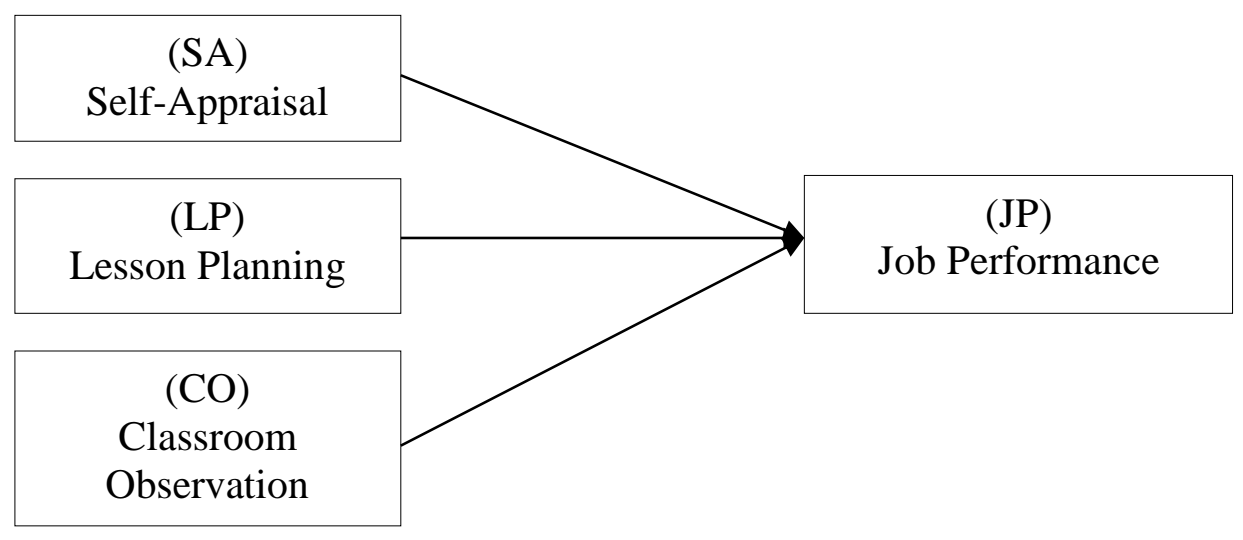

Figure 1. The Study's Conceptual Model 


\section{METHODOLOGY}

\section{Population and Sample}

One hundred and ten $(\mathrm{N}=110)$ male teachers working at the KMI Islamic boarding school in Gontor were involved in the study. This number constituted about $85 \%$ of the total population of teachers serving in the school. They were all male as the school was specified for male students only. The sample comprised relatively young teachers with a teaching experience of between two and five years. Table 1 provides further information about the sample.

Table 1

Characteristics of the Sample $(\mathrm{N}=110)$

\begin{tabular}{lll}
\hline Background Characteristics & $\mathrm{N}$ & $\%$ \\
\hline Age & & \\
- $16-20$ & 16 & 14 \\
- $21-25$ above & 84 & 76 \\
Academic Qualifications & 10 & 9.1 \\
- KMI level & & \\
- Bachelor's Degree & 83 & 75 \\
Years of Teaching Experience & 27 & 24 \\
- Two & & \\
- Three & 22 & 20 \\
- Four & 24 & 21 \\
\hline
\end{tabular}

\section{Instrument}

The study used a-35 item questionnaire to capture the teachers' perceptions of the methods used by the Islamic school to assess their performance. The questionnaire items were drawn from textbooks and partly adapted from Muwanguzi (2010). The items measured four constructs, i.e., classroom observation, lesson planning, and self-appraisal as the predictor variables, and teachers' job performance as the criterion variable. The respondents indicated their degree of agreement and disagreement to the items on a 6-point Likert scale which consisted of Strongly Disagree, Slightly Disagree, Disagree, Slightly Agree, Agree, and Strongly Agree. The reliability indexes for the data derived from these items were 0.74 for classroom observation (CO), 0.74 for self-appraisal (SA), 0.72 for lesson planning (LP), and 0.77 for teachers' job performance.

\section{Data Analysis}

The unit of analysis for this study was the school teachers; therefore, each respondent's scores were aggregated based on the extent of their perceptions of the variables observed. The independent variables were the three methods of performance appraisal, i.e. CO, SA and LP, while the dependent variable was job performance. The first level of analysis involved using descriptive statistics to profile the teachers' perceptions of each TPA method and their job performance, from which mean scores were derived to indicate the respondents' perception level. Based on the mean 
scores, three categories of thresholds (i.e., high, moderate, and low) were used to describe the perceived levels of the TPA methods used by the school. The thresholds are shown in Table 2 below:

Table 2

Thresholds Indicating the Levels of Teachers' Performance Appraisal

\begin{tabular}{cc}
\hline Thresholds & Level of Performance Appraisal \\
\hline $1.00-2.66$ & Low \\
$2.67-4.33$ & Moderate \\
$4.34-6.00$ & High \\
\hline
\end{tabular}

The categories were derived from the following formula (Mustika, 2009):

$$
\text { (Highest score - lowest score }) \div(\text { index score })
$$

where the computed scores for all methods would fall between 1 and 6 . A sample calculation for an index is: $\frac{(6-1)}{3}=1.66$. Additionally, the thresholds for the teachers' perceptions of their job performance were computed using the following formula (Mustika, 2009):

$$
\text { (Highest score - lowest score }) \div(\text { index score })
$$

The score of teacher performance will move between $1-5$, while the interval score is: $\frac{(5-1)}{3}=1.33$. To simplify the interpretation, the following categories were used to indicate the respective levels (Table 3):

Table 3

Thresholds Indicating the Levels of Teachers' Job Performance

\begin{tabular}{cc}
\hline Thresholds & Level of Performance Appraisal \\
\hline $1.00-2.33$ & Low \\
$2.34-3.66$ & Moderate \\
$3.67-5.00$ & High \\
\hline
\end{tabular}

\section{Interpreting the Strength of Correlation Coefficients}

Pearson correlation analysis was run on the TPA data to see the associations between the three methods and teachers' job performance. Taylor's (1990) guidelines were used to decide whether a correlation between a TPA method and job performance is weak, moderate, strong, or very strong. Taylor (1990) wrote that, "correlation coefficients (in absolute value) which are $<0.35$ are considered to represent low or weak correlations, 0.36 to 0.67 modest or moderate correlations, and 0.68 to 1.0 strong or high correlations with $r$ coefficients $>0.90$ very high correlations" (p. 37). 


\section{RESULTS}

Thirty-five items representing the three methods of TPA and teachers' job performance were used to assess each variable in the study. Teachers' responses to them are discussed in the following sections.

\section{Perceptions towards Classroom Observation as a TPA Method}

Table 4 shows teachers' perceptions towards the school's use of classroom observation as a performance appraisal method.

Table 4

Perceptions towards Classroom Observation ( $\mathrm{N}=110)$

\begin{tabular}{|c|c|c|c|c|}
\hline \multirow{2}{*}{ Items } & \multicolumn{2}{|c|}{ Response Categories } & \multirow{2}{*}{ M } & \multirow{2}{*}{ SD } \\
\hline & Disagree & Agree & & \\
\hline $\begin{array}{l}\text { 1. I understood the observation instrument } \\
\text { before I was assessed }\end{array}$ & $\begin{array}{c}6 \\
(5.5 \%)\end{array}$ & $\begin{array}{c}104 \\
(94.5 \%)\end{array}$ & 4.77 & 0.77 \\
\hline $\begin{array}{l}\text { 2. The results of the observations are } \\
\text { adequately explained to me }\end{array}$ & $\begin{array}{c}4 \\
(3.6 \%)\end{array}$ & $\begin{array}{c}106 \\
(96.4 \%)\end{array}$ & 4.99 & 0.74 \\
\hline $\begin{array}{l}\text { 3. The results of the observations caused me } \\
\text { to make changes and improvements }\end{array}$ & $\begin{array}{c}1 \\
(0.9 \%)\end{array}$ & $\begin{array}{c}109 \\
(99.1 \%)\end{array}$ & 5.39 & 0.59 \\
\hline $\begin{array}{l}\text { 4. The observation has a positive impact on } \\
\text { students' learning process }\end{array}$ & $\begin{array}{c}0 \\
(0 \%)\end{array}$ & $\begin{array}{c}110 \\
(100 \%)\end{array}$ & 5.27 & 0.66 \\
\hline $\begin{array}{l}\text { 5. The observer has an adequate } \\
\text { understanding of good teaching practices }\end{array}$ & $\begin{array}{c}0 \\
(0 \%)\end{array}$ & $\begin{array}{c}110 \\
(100 \%)\end{array}$ & 5.13 & 0.61 \\
\hline $\begin{array}{l}\text { 6. The observer has an adequate } \\
\text { understanding of the subject content } \\
\text { being taught by teachers in the classroom }\end{array}$ & $\begin{array}{c}1 \\
(0.9 \%)\end{array}$ & $\begin{array}{c}109 \\
(99.1 \%)\end{array}$ & 5.07 & 0.74 \\
\hline $\begin{array}{l}\text { 7. The observer in my classroom is well } \\
\text { trained }\end{array}$ & $\begin{array}{l}5 \\
(4.5 \%)\end{array}$ & $\begin{array}{c}105 \\
(95.5 \%)\end{array}$ & 4.97 & 0.84 \\
\hline $\begin{array}{l}\text { 8. Classroom observations caused me to feel } \\
\text { stressed }\end{array}$ & $\begin{array}{c}79 \\
(71.8 \%)\end{array}$ & $\begin{array}{c}31 \\
(28.2 \%)\end{array}$ & 2.78 & 1.36 \\
\hline $\begin{array}{l}\text { 9. Formal classroom observations are } \\
\text { helpful for improving my teaching }\end{array}$ & $\begin{array}{c}1 \\
(0.9 \%)\end{array}$ & $\begin{array}{c}109 \\
(99.1 \%)\end{array}$ & 5.02 & 0.73 \\
\hline $\begin{array}{l}\text { 10. I don't have any objection when a senior } \\
\text { teacher observes my teaching }\end{array}$ & $\begin{array}{c}34 \\
(30.9 \%)\end{array}$ & $\begin{array}{c}76 \\
(69.1 \%)\end{array}$ & 3.83 & 1.34 \\
\hline & & & 4.72 & 0.837 \\
\hline
\end{tabular}

Note $:$ Agree $=($ Slightly Agree + Agree + Strongly Agree $) ;$ Disagree $=($ Strongly Disagree + Slightly Disagree + Disagree $)$

The distribution of responses shows that all the teachers rated the $\mathrm{CO}$ method, its impact and the observers involved quite positively. All approved that classroom observation had a positive impact on students' learning process (100\%), caused them to make changes and improvements (99.1\%), and helped to improve their teaching (99.1\%). It appeared that their appraisal was done properly by the school as the teachers were made to understand the instrument (i.e., assessment criteria) prior to the observation $(94.5 \%)$ and were informed of the results thereafter (96.4\%). Additionally, the observers were perceived as knowledgeable about the practices of 
good teaching (100\%) and the content being taught during the observation (99.1\%); they were also perceived to be well-trained $(95.5 \%)$. However, the method caused some teachers to feel stressed and uncomfortable (28.2\%). Close to one-third preferred not to be observed by a senior teacher $(31 \%)$. The mean rating for $\mathrm{CO}$ is 4.72 , which indicates a high or favorable rating as a TPA method.

\section{Perceptions towards Self-Appraisal as a TPA Method}

Table 5 shows teachers' perceptions towards the school's use of self-appraisal as a performance appraisal method.

Table 5

Perceptions towards Self-Appraisal $(\mathrm{N}=110)$

\begin{tabular}{|c|c|c|c|c|}
\hline \multirow{2}{*}{ Items } & \multicolumn{2}{|c|}{ Response Categories } & \multirow{2}{*}{ M } & \multirow{2}{*}{ SD } \\
\hline & Disagree & Agree & & \\
\hline $\begin{array}{l}\text { 1. I am trained to do self-appraisal for my } \\
\text { teaching performance }\end{array}$ & $\begin{array}{l}3 \\
(2.7 \%)\end{array}$ & $\begin{array}{c}107 \\
(82.7 \%)\end{array}$ & 4.98 & 0.75 \\
\hline $\begin{array}{l}\text { 2. I know clearly the criteria used to self- } \\
\text { appraise }\end{array}$ & $\begin{array}{c}11 \\
(10 \%)\end{array}$ & $\begin{array}{c}99 \\
(90 \%)\end{array}$ & 4.81 & 0.9 \\
\hline $\begin{array}{l}\text { 3. I know the goals and objectives of my } \\
\text { teaching practice }\end{array}$ & $\begin{array}{c}0 \\
(0 \%)\end{array}$ & $\begin{array}{c}110 \\
(100 \%)\end{array}$ & 5.24 & 0.56 \\
\hline $\begin{array}{l}\text { 4. I prefer to do a self-appraisal than other } \\
\text { methods }\end{array}$ & $\begin{array}{c}10 \\
(9.1 \%)\end{array}$ & $\begin{array}{c}100 \\
(90.9 \%)\end{array}$ & 4.71 & 0.98 \\
\hline $\begin{array}{l}\text { 5. Self-appraisal is more objective } \\
\text { compared to other methods of appraisal }\end{array}$ & $\begin{array}{c}7 \\
(6.4 \%)\end{array}$ & $\begin{array}{c}103 \\
(93.6 \%)\end{array}$ & 4.65 & 0.99 \\
\hline $\begin{array}{l}\text { 6. I believe that self-appraisal should be } \\
\text { combined with other methods to make } \\
\text { it valid and reliable }\end{array}$ & $\begin{array}{c}20 \\
(18.2 \%)\end{array}$ & $\begin{array}{c}90 \\
(81.8 \%)\end{array}$ & 4.55 & 1.2 \\
\hline $\begin{array}{l}\text { 7. Through self-appraisal, I'm able to } \\
\text { identify my strengths and weaknesses } \\
\text { in my teaching }\end{array}$ & $\begin{array}{l}2 \\
(1.8 \%)\end{array}$ & $\begin{array}{c}108 \\
(98.2 \%)\end{array}$ & 5.18 & 0.71 \\
\hline \multirow[t]{2}{*}{$\begin{array}{l}\text { 8. I prefer self-appraisal as a method and } \\
\text { should not involve any one else in } \\
\text { appraising me }\end{array}$} & $\begin{array}{c}33 \\
(30 \%)\end{array}$ & $\begin{array}{c}77 \\
(70 \%)\end{array}$ & 4.08 & 1.02 \\
\hline & & & 4.77 & 0.89 \\
\hline
\end{tabular}

The table above shows that a majority of the teachers understood the goal and objectives of their teaching activities (100\%). Most preferred SA to other appraisal methods (91\%), believing it to be more objective (93.6\%) and effective in helping them to identify the strengths and weaknesses of their teaching (98.2\%). Most also felt they were well-trained in self-appraisal $(82.7 \%)$, and knew the criteria well $(90 \%)$. While a majority were of the view that SA should be integrated with other appraisal methods $(81.8 \%)$, some felt it self-sufficient. About $30 \%$ of the teachers agreed their appraisal should be done by themselves and not involve other parties. This means that close to one-third did not welcome the idea of being appraised by another person. The mean rating for SA as a TPA method is 4.77 , slightly higher than $\mathrm{CO}$, and indicates a high or favorable rating. 


\section{Perceptions towards Lesson Planning as a TPA Method}

Table 6 shows teachers' perceptions towards the school's use of lesson planning as a performance appraisal method.

Table 6

Perceptions towards Lesson Planning $(\mathrm{N}=110)$

\begin{tabular}{|c|c|c|c|c|}
\hline \multirow{2}{*}{ Items } & \multicolumn{2}{|c|}{ Response Categories } & \multirow{2}{*}{ M } & \multirow{2}{*}{$\mathrm{SD}$} \\
\hline & Disagree & Agree & & \\
\hline $\begin{array}{l}\text { 1. Using lesson plan as appraisal method } \\
\text { is very objective as teachers are trained } \\
\text { well in planning their lesson }\end{array}$ & $\begin{array}{c}5 \\
(4.5 \%)\end{array}$ & $\begin{array}{c}105 \\
(95.5 \%)\end{array}$ & 4.94 & 0.87 \\
\hline $\begin{array}{l}\text { 2. Lesson planning helps teachers to } \\
\text { manage the actual teaching practice in } \\
\text { the classroom }\end{array}$ & $\begin{array}{c}45 \\
(40.9 \%)\end{array}$ & $\begin{array}{c}65 \\
(59.1 \%)\end{array}$ & 3.85 & 1.27 \\
\hline $\begin{array}{l}\text { 3. Lesson planning does not assist the } \\
\text { teacher to organize instructional time } \\
\text { and is therefore not preferred as a } \\
\text { method of appraisal }\end{array}$ & $\begin{array}{c}56 \\
(50.9 \%)\end{array}$ & $\begin{array}{c}54 \\
(49.1 \%)\end{array}$ & 3.59 & 1.24 \\
\hline $\begin{array}{l}\text { 4. Using lesson planning as a method of } \\
\text { appraisal is not effective because } \\
\text { effective lessons cannot be fully } \\
\text { described in a lesson plan }\end{array}$ & $\begin{array}{c}46 \\
(41.8 \%)\end{array}$ & $\begin{array}{c}64 \\
(58.2 \%)\end{array}$ & 3.71 & 1.27 \\
\hline $\begin{array}{l}\text { 5. Using lesson planning as a method of } \\
\text { appraisal does not take into account the } \\
\text { teacher's flexibility in actual teaching }\end{array}$ & $\begin{array}{c}48 \\
(43.6 \%)\end{array}$ & $\begin{array}{c}62 \\
(56.4 \%)\end{array}$ & 3.83 & 1.31 \\
\hline $\begin{array}{l}\text { 6. Lesson planning should be combined } \\
\text { with other methods to make the } \\
\text { appraisal system more effective }\end{array}$ & $\begin{array}{c}15 \\
(13.6 \%)\end{array}$ & $\begin{array}{c}95 \\
(86.4 \%)\end{array}$ & 4.57 & 1.04 \\
\hline \multirow[t]{2}{*}{$\begin{array}{l}\text { 7. Lesson planning as a method of } \\
\text { appraisal is not preferred because } \\
\text { overall effectiveness of a lesson cannot } \\
\text { be evaluated through the use of lesson } \\
\text { plans only }\end{array}$} & $\begin{array}{c}46 \\
(41.8 \%)\end{array}$ & $\begin{array}{c}64 \\
(58.2 \%)\end{array}$ & 3.72 & 1.27 \\
\hline & & & 4.00 & 1.17 \\
\hline
\end{tabular}

Lesson planning was perceived less favorably by the teachers compared to classroom observation and self-appraisal. Although $95.5 \%$ perceived it as an objective appraisal method, more than half of the sample thought that it cannot fully capture effective lessons (58.2\%), nor can it capture a teacher's flexibility or teaching talent in the classroom (56.4\%). About 86\%-which is about $5 \%$ more than the rating of SA on this--agreed it should be combined with other methods of appraisal to fully determine teachers' performance. The overall rating of lesson planning as a TPA method was 4.00 , lower than the previous two methods, but still regarded as high.

\section{Teachers' Perceptions of the TPA Methods Used by the School}

The overall analysis (Table 7) was based on the means and standard deviations of all items 
measuring the three TPA methods. The mean score for classroom observation is 4.72 with a standard deviation of .837 . For self-appraisal, $\mathrm{M}=4.77$ with an $\mathrm{SD}=.890$, while for lesson planning, $M=4.00$ with an $\mathrm{SD}=1.172$. Based on the scale used to indicate the level, selfappraisal and classroom observation have high mean scores, while that of lesson planning is moderate at 4.00 .

Table 7

Means and Standard Deviations of Each TPA Method $(\mathrm{N}=110)$

\begin{tabular}{clcc}
\hline No & \multicolumn{1}{c}{ TPA Methods } & M & SD \\
\hline 1 & Classroom Observation & 4.72 & .837 \\
2 & Self-Appraisal & 4.77 & .890 \\
3 & Lesson planning & 4.00 & 1.172 \\
\hline
\end{tabular}

\section{Teachers’ Job Performance}

Ten Likert items measured teachers' job performance in this study. The overall mean of teachers' job performance is $4.01(\mathrm{SD}=.80)$ indicating a high level of job performance perceived by the teachers teaching at the Islamic boarding school. Table 8 shows the frequencies, percentages, means and standard deviations of all the items.

Table 8

Teachers' Job Performance $(\mathrm{N}=110)$

\begin{tabular}{|c|c|c|c|c|c|}
\hline \multirow{2}{*}{ Items } & \multicolumn{3}{|c|}{ Response Categories } & \multirow{2}{*}{ M } & \multirow{2}{*}{$\mathrm{SD}$} \\
\hline & $\mathrm{N} \& \mathrm{R}$ & $S$ & $F \& A$ & & \\
\hline $\begin{array}{l}\text { 1. I participated actively in } \\
\text { co-curricular activities } \\
\text { in my school }\end{array}$ & $\begin{array}{c}3 \\
(2.7 \%)\end{array}$ & $\begin{array}{c}28 \\
(25.5 \%)\end{array}$ & $\begin{array}{c}79 \\
(71.8 \%)\end{array}$ & 3.85 & 0.82 \\
\hline $\begin{array}{l}\text { 2. I am involved in setting } \\
\text { goals for my school }\end{array}$ & $\begin{array}{c}23 \\
(20.9 \%)\end{array}$ & $\begin{array}{c}36 \\
(32.7 \%)\end{array}$ & $\begin{array}{c}51 \\
(46.5 \%)\end{array}$ & 3.26 & 1.3 \\
\hline $\begin{array}{l}\text { 3. I supervise my students } \\
\text { in their activities }\end{array}$ & $\begin{array}{c}2 \\
(1.8 \%)\end{array}$ & $\begin{array}{c}14 \\
(12.7 \%)\end{array}$ & $\begin{array}{c}94 \\
(85.5 \%)\end{array}$ & 4.16 & 0.71 \\
\hline $\begin{array}{l}\text { 4. I prepare a scheme of } \\
\text { work at the beginning of } \\
\text { every term }\end{array}$ & $\begin{array}{c}5 \\
(4.50 \%)\end{array}$ & $\begin{array}{c}56 \\
(50.9 \%)\end{array}$ & $\begin{array}{c}49 \\
(44.5 \%)\end{array}$ & 3.46 & 0.73 \\
\hline $\begin{array}{l}\text { 5. I prepare a lesson plan } \\
\text { before the actual } \\
\text { teaching }\end{array}$ & $\begin{array}{c}0 \\
(0 \%)\end{array}$ & $\begin{array}{l}2 \\
(1.8 \%)\end{array}$ & $\begin{array}{c}108 \\
(98.2 \%)\end{array}$ & 4.65 & 0.52 \\
\hline $\begin{array}{l}\text { 6. I manage classroom } \\
\text { records actively }\end{array}$ & $\begin{array}{c}6 \\
(5.5 \%)\end{array}$ & $\begin{array}{c}42 \\
(38.2 \%)\end{array}$ & $\begin{array}{c}62 \\
(56.4 \%)\end{array}$ & 3.67 & 0.85 \\
\hline $\begin{array}{l}\text { 7. I participate in staff } \\
\text { meetings }\end{array}$ & $\begin{array}{c}11 \\
(10 \%)\end{array}$ & $\begin{array}{c}21 \\
(19.1 \%)\end{array}$ & $\begin{array}{c}78 \\
(70.9 \%)\end{array}$ & 3.89 & 1.04 \\
\hline $\begin{array}{l}\text { 8. I try to align my } \\
\text { instructional objectives } \\
\text { with the school's vision }\end{array}$ & $\begin{array}{c}3 \\
(2.70 \%)\end{array}$ & $\begin{array}{c}5 \\
(4.5 \%)\end{array}$ & $\begin{array}{c}102 \\
(92.7 \%)\end{array}$ & 4.33 & 0.69 \\
\hline
\end{tabular}


1. I am involved in guiding and counselling students

2

23

$(20.9 \%)$

0

$(0 \%)$
85

$(77.3 \%)$

$4.11 \quad 0.83$

109

$(99.1 \%)$ the expected norms

Note: $N=$ Never,$R=$ Rarely, $S=$ Seldom $F=$ Frequently, $A=$ Always

The figures show that huge majorities of the teachers make it their responsibility to discipline students (99\%), prepare a lesson plan before teaching (98\%), and align instructional objectives with the school's mission and vision (93\%). Additionally, most teachers also supervised their students' activities (85.5\%), guided and counseled students (77\%), participated in staff meetings $(71 \%)$, and took part in co-curricular activities $(72 \%)$. However, less than half prepared a scheme of work (44.5\%) and participated in goal setting for the school $(46.5 \%)$.

\section{Relationship between Perceived Uses of Appraisal Methods and Teachers' Job Performance}

To address this question, the study ran Pearson's correlation analyses to examine the relationships between perceived uses of the TPA methods and job performance. Table 9 summarizes the results.

Table 9

Correlations between Perceived Uses of the TPA Methods and Job Performance $(\mathrm{N}=110)$

\begin{tabular}{llc}
\hline Constructs & Correlation Coefficient $(r)$ & Strength of Correlation \\
\hline 1. CO and JP & $.251^{* *}$ & weak \\
2. SA and JP & $.463^{* *}$ & moderate \\
3. LP and JP & -.143 & weak \\
4. CO and SA & $.471^{* *}$ & moderate \\
5. CO and LP & $.188^{*}$ & weak \\
6. SA and LP & -.113 & weak \\
7. Overall TPA and JP & $.187^{*}$ & weak
\end{tabular}

Note: $C O=$ classroom observation; $S A=$ self-appraisal; $L P=$ lesson plan; JP = job performance; **statistically significant at $p$ $<0.01$; *statistically significant at $p<0.05$

Two of the three bivariate correlations were statistically significant. More precisely, classroom observation and self-appraisal were positively correlated with teachers' job performance; classroom observation at $r(109)=.251, p=.008$, and self-appraisal at $r(109)=.463, p=0.001$. Therefore, the null hypotheses for these associations were rejected. Although significant, the strength of these associations is weak, or at best, moderate.

Meanwhile, lesson planning was negatively correlated with job performance, $r(109)=$ -.143, $p=.137$. Therefore, the null hypothesis was accepted, which means there is no statistically significant relationship between lesson planning and job performance among teachers teaching at the Islamic boarding school in Gontor. In addition, statistically significant positive relationships were observed between classroom observation and self-appraisal, $r(109)$ 
$=.471, p=.001$; and between classroom observation and lesson planning, $r(109)=.188, p=$ .05 . That between self-appraisal and lesson planning was negatively correlated, $r(109)=-.113$, $p=.240$.

\section{DISCUSSION AND CONLUSION}

Based on a high construct mean of 4.77 , this research revealed that most teachers at the Gontor Islamic boarding school perceived self-appraisal as the most effective TPA method. It was rated the highest among the three predictor variables. Specifically, teachers perceived self-appraisal as a comprehensive and viable TPA approach. Their rating of this method also underlies their attitude towards instructional improvement. Teachers agreed that classroom observation and lesson planning were moderately used by the school as TPA methods.

The study also discovered positive correlations between two TPA methods, i.e., classroom observation and self-appraisal, and teachers' job performance, while lesson planning was negatively correlated. Wanyama (2001) earlier observed that teachers would require close and frequent supervision to maintain a consistent performance. Teachers tend to benefit tremendously from the feedback given to them after every appraisal exercise. Recommendations for improvement that come after feedback discussions enable teachers to further enhance their professionalism as part of a broader professional growth strategy.

From the practical perspective, the findings of the study are relevant not only for teachers, school boards and school principals of Gontor 1 as the main campus, but also for all schools operating in Gontor and schools with a similar curriculum and characteristics. Based on the results, the study suggests that school boards and school principals adopt and implement effective appraisals in order to develop teachers' instructional efficacy and job performance. The outcomes of the study indicate that a combination of the three TPA methods would significantly influence the development of teachers' professionalism in school. School boards, school principals and educators should, therefore, maximize the use of these methods by giving informative feedback to further motivate teachers to excel at what they do.

In conclusion, performance appraisal guides school leaders to support and accomplish the aims of instructional improvement. Such assessment is crucial for the sustainability of instructional improvement for teachers in schools. Teachers' appraisal is a paramount and credible means to enhance instructional improvement. Taking into account this factor, it is vital that school leaders implement an effective TPA since it is a powerful method for developing high quality and meaningful teaching and learning. 


\section{REFERENCES}

Armstrong (2003). A handbook of human resource management practices. (8th ed.), Kogan page Us Limited.

Blandford, S. (2000), Managing professional development in schools. Online Research Library: Questia.

Danielson, C., \& McGreal, T. L. (2000). Teacher evaluation to enhance professional learning. Princeton, NJ: Educational Testing Service.

Darling Hammond. (1999). Teacher quality and student achievement; A review of state Policy evidence. Sealtle center for the study of teaching and policy: University of Washington

Denner, P.R., Salzman, S.A. \& Bangert, A.W. (2001). Examining the validity of the teacher work sample: A study of rater differences in scoring. University of Northern Iowa

Elliott, K. (2015). Teacher Performance Appraisal: More about Performance or Development?. Australian Journal of teacher education, 40(9), n9.

Hora, M. T., \& Ferrare, J. J. (2013). Instructional systems of practice: A multidimensional analysis of math and science undergraduate course planning and classroom teaching. Journal of the Learning Sciences, 22(2), 212-257.

Ingvarson, L. (2003). A professional development system fit for a profession. In V. Zbar and T. Mackay (Eds.), leading the education debate: Selected papers from a decade of the IARTV Seminar Series (pp. 391-408). Melbourne, VIC: Incorporated Association of Registered Teachers of Victoria (IARTV).

Kibet Bii, H., \& Wanyama, P. (2001). Automation and its impact on the job satisfaction among the staff of the Margaret Thatcher Library, Moi University. Library Management, 22(6/7), 303-310.

Matters, C., Oliva, M. \& Laine, S.W.M. (2008). Improving instruction through effective teacher evaluation: Options for states and districts, Teacher Quality Research and Policy Base, National Comprehensive Center for Teacher Quality.

Mulford, B. (2007a) Overview of research on Australian Educational leadership 2001-2005, Monograph, 40 (Melbourne: Australian Council for Educational Leaders)

Mustika (2009). Statistik Penelitian. Bandung: FMIPA UPI.

Muwanguzi, E. (2010). Appraisal practices and teacher performance in the secondary schools of Nansana Town Council, Wakiso District. Unpublished Research Dissertation for the Degree of Master of Science (Human Resource), Makarere University, Uganda. Retrieved

Nur Listiawati (2003), Teacher Appraisal in Indonesia, Journal of Southeast Asian Education , 4 (2). 
Roelofs, E. \& Sanders, P. (2007). Towards a Framework for Assessing Teacher Competence, European journal of Vocational Training. 40(1), 123-139.

Stronge, J. H. (2006). Teacher evaluation and school improvement: Improving the educational landscape. In J. H. Stronge (Ed.), Evaluating teaching: A guide to current thinking and best practice. (2nd ed., pp. 1-23). Thousand Oaks, CA: Corwin Press.

Taylor, R. (1990). Interpretation of the correlation coefficient: a basic review. Journal of diagnostic medical sonography, 6(1), 35-39.

Vecchio, R. P., \& Anderson, R. J. (2009). Agreement in self-other ratings of leader effectiveness: The role of demographics and personality. International Journal of Selection and Assessment, 17(2), 165-179.

Verspoor, A. (2008). At the Crossroads: choices for secondary education in Sub-Saharan Africa. Washington: The World Bank.

Wheeler, P., \& Haertel, G. D. (1993). Resource Handbook on Performance Assessment and Measurement: A Tool for Students, Practitioners, and Policymakers. Owl Press, PO Box 89, Berkeley, CA 94701. 